\title{
Integration of Siak Songket Weaving Values Through Value Clarification Technique to Reinforcement of the Meaningful History Learning
}

\author{
$1^{\text {st }}$ Bedriati Ibrahim* \\ Department of History Education, \\ Faculty of Teacher Training and Education, \\ Riau University, Pekanbaru, Indonesia \\ ibrahimbedriati@gmail.com \\ $2^{\text {nd }}$ Asyrul Fikri \\ Department of History Education, \\ Faculty of Teacher Training and Education, \\ Riau University, Pekanbaru, Indonesia
}

\author{
$3^{\text {rd }}$ Piki Setri Pernantah \\ Department of History Education, \\ Faculty of Teacher Training and Education, \\ Riau University, Pekanbaru, Indonesia
}

\begin{abstract}
The Siak Songket weaving is one of local cultural from Riau Malay land. The SiakSongket weaving can not only be used as clothing but certainly has a high noble value. Integrating the values of this local wisdom in learning history is necessary to contribute in order to strengthen the nation's identity to students and realize the meaningful learning. This study aims to produce a learning innovation that integrates the values of local wisdom in learning history through a value clarification technique approach. The choice of value clarification technique approach in this study is very relevant to the purpose of the
\end{abstract}

\section{INTRODUCTION}

The learning is essentially the process of adding insight, information and the ability of the subject students. Therefore, the effort to add information and increase the competence of learners becomes important, so at that time teachers should think about what strategies should be done so that the purpose that wants to be achieved effectively and efficiently. It is very important to understand each teacher because what will be accomplished will determine how the teacher has to accomplish it.

The learning innovation continues to be made to make ideal learning that is relevant to model to develop the good character and critical thinking ability of students, therefore, it can create reflective thinking. This approach can also make students choose values, express values, and actualize values into the behavior of life in society. History learning is no longer just transfer of knowledge but also transfer of values to students. Such a history learning situations will be creating meaningful learning and relevant to 21st century education based on values and character.

Keywords-Siak Songket Weaving, Values Integration, Value Clarification Technique History Learning

the needs and challenges of today. Learning in the 21st century is still working to create learning conditions that teach learners. Learning continues to prioritize student-center activities, students are expected to be more critical, innovative, creative and active. The emergence of consciousness in the learners to learn so that the process of change attitudes, attitudes, and insight. The students are also able to further enhance their skills in accordance with the objectives of the 2013 curriculum revision with the $21^{\text {st }}$ century learning concept.

The $21^{\text {st }}$ century learning is expected to also be able to train and instill a democratic attitude 
for students and create a fun learning atmosphere so that students are able to learn by developing their potential and ability to develop its creativity that impacts the improvement of learning quality. Fun learning is a learning that is scarred and meaningful for learners. The students feel the significance of the learning process so that there is a relationship between aspects, concepts, information or new situations with relevant components within the student's competency structure. Learning is not merely to memorize and to know. Like his history learning, the study of history in school is not merely memorizing mere concepts or facts, but it is an activity of linking concepts to generate complete understanding, so the concept of being well understood and not easily forgotten. After all, many of the values and messages contained in these historical facts or events can improve the competence of students.

The meaningful history learning is perfectly suited to the desires achieved by the 2013 curriculum, which is closely related to the theory of Vygotsky's Constructivism (Social and Emancipator Constructivism). This theory argues that students are trying to construct knowledge or create meaning as a result of thinking and interacting in a social context. This learning theory is a theory of the creation of meaning, also relevant to the scientific approach and value clarification technique that seeks to make the learning of history more meaningful with the integration of values done through innovation learning done by history teachers.

The history education is not only meant for students to know and memorize about the events of the nation's past peoples and countries but how they can make knowledge and understanding of history as an ingredient of self-reflection in understanding the dynamics of life today so that in them grows and develops a sense of love and responsibility towards his people. Besides that, the history education in school aims to develop the potential of learners to think chronologically and critically analytical and can understand history with good and true [1]. From this, it can be understood that the history learning in school is not only transfer of knowledge but also must transfer of values so that the history learning becomes more meaningful and effective for the students. This is what will trigger many people to more love of learning history.

Haryonosaid that it is necessary to history education at the level of primary and secondary education not to create a historian, but it is preferable to equip students to anticipate the problems of life Thus have self-autonomy [2]. It has been proper to be realized by history teachers. Historical knowledge is a necessity, but history's meaningfulness to self-learners must also be kept in mind. The history learning is no longer merely the teacher conveys information about historical facts, then learners are faced with problematical problems and are asked to solve them. More than those teachers should also consider the benefits for learners to face problems in everyday life.

The given the importance of meaningful history learning, there needs to be an innovation of historical reforming done by teachers. Teachers are required to develop value-based history learning to realize meaningful history learning. The values that are integrated into the history learning can be sourced from local wisdom or local history, which of course is also relevant to the condition of the students and the values them understanding. Kartodirdjosaid history learning should use a lokocentric approach, which is the history learning with local history [3]. In order for learning to be more meaningful or high value, teachers can use who can internalize the values therein, which is the model Value Clarification[4]. Thus, the process of integrating values into learning can be done through the VCT (Value Clarification Technique) approach in the scientific history learning framework (in accordance with the Curriculum 2013).

The embodiment of meaningful history learning with values integration is, in fact, relevant to the 21st-century learning needs that contribute to the strengthening of character education, in addition to Literation, 4C, and HOTS. In addition, the 2013 curriculum actually also accommodates the $21^{\text {st }}$ century skills, whether seen from competency standards, content standards, process standards, and standards of judgment. The character values developed in learning can be sourced from local 
values. For that, this article seeks to describe the innovations of the history learning process based on value to the realization of more meaningful and enjoyable history learning.

\section{METHOD}

This research uses the method of research and development of a learning system that is model 4D. Model 4D is one of the systematic learning design models. The main Stage 4-D development model is Define, Design, Develop, and Disseminate or adapted into the 4-P model, which is pendefinisian (defining), perancangan (designing), pengembangan (developing), and penyebaran (spreading) [5]. The 4D development method is not much different from the other product development methods, but this development procedure is shorter because the resulting product is not too risk and the system impacts are limited to targeted students. The define stage; this research conducts the need for the development of this model, namely the development of a history learning model based on the value of local wisdom of Riau. In the design stage, this research has made the product initial (prototype) or product design. In addition, this stage is also carried out activities with activities to prepare conceptual frameworks of models and learning devices (materials, media, and evaluation tools). In the developing stage, the research in this stage is divided into two activities: expert appraisal and developmental testing. Validation by model and material experts, where all advice given by experts is used to improve the material and design of the learning model that has been made. Furthermore, trials or implementation tests for the model were developed. The disseminate stage is the deployment step of the model developed, which is the packaging of a learning model by printing manual model use of learning and convey the results of model development in scientific forums or seminars.

\section{RESULTS AND DISCUSSION}

\section{The History Learning}

The history learning is the process of internalizing values, the meaning of past events, origins, collective experience, wisdom and the thoroudication of historical actors [6]. Historical awareness will strengthen the existence and identity and personality of a nation to realize the character-building national through the pride of the history and culture of the nation of Indonesia so that the inheritance of the noble values of the nation remains preserved [7].

The process of history learning at school is expected to implement 2 things: the process of increasing knowledge and transfer of values, so as not only play a role in knowing various facts and historical events but also able to the reflection of what is known. Presenting historical facts or events is very important, but reviewing the essence and meaning behind every historical event is something that should not be forgotten in history learning [8]. The good history learning is not limited to factual knowledge alone, but students are required to be able to understand the development of historical events imaginatively and analytically [9]. Further Susantoexplains that a person can have a history understanding if the former has known the concept of history, then internalize the historical event, and then from that passion will be able to capture the meaning contained in the event [10].

The history learning innovations are indispensable to make history subjects as effective media in building student characters [10]. For, the history education plays a role in character education because history lessons have a strategic meaning in the formation of dignified character and civilization and in the formation of Indonesian people who have a national flavor and love the homeland [11]. Value-based history learning is a form of learning innovation that can be done through the development of models, media, and teaching materials on history learning.

\section{The Siak Songket Weaving}

The Siak Songket weaving is a hereditary cultural heritage that has to be guarded by its sustainability and become the pride of the Riau people. The Riau Malay women who contributed greatly to developing the Songket weaving craft Siak is TengkuMaharatu. TengkuMaharatu was the second consort of Sultan SyarifKasim II, after the first Empress, TengkuAgung died. The manufacture of this cloth is done by going through a process of 
making a yarn interspersed with woven gold thread or silver thread with a variety of motifs or patterns of the weave. This songket cloth originated from Siak. Beginning at the time of the Sultanate of Siak moved the center of his administration from Siak to Pekanbaru. The center of the Sultanate made the Malay Cultural Center move to Pekanbaru[12]. The songket weaving has a value for clothing. In the social life of Riau Malay Society, clothing not only serves to protect the body from heat and cold, but all clothing is always associated with social norms, religions, customs so that clothing in Riau Malay developed with variegated meanings.

The Siaksongket weaving has a high noble value and manifested in various forms and patterns that certainly also have a philosophy and symbolic meaning in the life of Riau people.
The durability of Songket weaving crafts Riau to this day, is not separated from the active role of the people of the culture, who use and defend it [13]. The songket weaving pattern of Riau Malay is derived from the form of flora, fauna and celestial objects that are treated in certain forms [14]. Once the craftsmen were required to understand the meaning and philosophy contained in each motif, it was intended to be personally able to absorb and internalize the values in question, able to disseminate, and able to also put motives according to the groove and its fault [15]. From the types and patterns of the SiakSongket, this research tries to reconstruct the values contained therein, by validating experts with experts in Malay culture. Here can be seen various patterns of the Siaksongket weaving Siak and the value contained in it, namely:

Table 1. The Name of Patterns, Meaning of Patterns and Values Contained in The Siak Songket Weaving

\begin{tabular}{|c|c|c|}
\hline $\begin{array}{l}\text { Name of } \\
\text { Patterns }\end{array}$ & Meaning of Patterns & $\begin{array}{l}\text { Values } \\
\text { Contained }\end{array}$ \\
\hline $\begin{array}{l}\text { Tampuk } \\
\text { Manggis }\end{array}$ & $\begin{array}{l}\text { Tampuk manggis bunga hutan } \\
\text { Ditekat menjadi bunga bertabur } \\
\text { Elok manis barang kelakuan } \\
\text { Diingat orang sampai kekubur }\end{array}$ & $\begin{array}{l}\text { wisdom } \\
\text { good } \\
\text { behavior }\end{array}$ \\
\hline $\begin{array}{l}\text { Pucuk } \\
\text { Rebung }\end{array}$ & $\begin{array}{l}\text { Hiasan pucuk rebung penuh } \\
\text { Bagaikan bintang isi di dalam } \\
\text { Perangai elok laku senonoh } \\
\text { Habislah hutang hilanglah dendam }\end{array}$ & $\begin{array}{l}\text { happiness } \\
\text { patience }\end{array}$ \\
\hline $\begin{array}{l}\text { Bunga } \\
\text { melati }\end{array}$ & $\begin{array}{l}\text { Memakai hiasan bunga melati } \\
\text { Muka jernih hati pun suci } \\
\text { Sengketa jauh hasad berhenti } \\
\text { Berkah mengalir tiada henti }\end{array}$ & $\begin{array}{l}\text { gratitude } \\
\text { harmony }\end{array}$ \\
\hline $\begin{array}{l}\text { Siku } \\
\text { keluang }\end{array}$ & $\begin{array}{l}\text { Hiasan siku keluangbanji } \\
\text { Berpadan dengan semut beriring } \\
\text { Tanda berilmu memegang janji } \\
\text { Tanda berkawan jalan seiring }\end{array}$ & $\begin{array}{l}\text { responsible } \\
\text { brotherhood }\end{array}$ \\
\hline Awan larat & $\begin{array}{l}\text { Hiasan kuntum bertangkai lengkap } \\
\text { Awan larat nama induknya } \\
\text { Dengan senyum merangkai cakap } \\
\text { Laut dan darat sama eloknya }\end{array}$ & $\begin{array}{l}\text { affection } \\
\text { splendor }\end{array}$ \\
\hline
\end{tabular}

Guslinda \& Kurniaman explained that the weaving songket of Siak type more in the form of completeness of traditional clothing, such as:
King's clothes, bridal clothing, and the welcome attire of the guest's honor.Besides, the songket weaving of Siak is also used for the uniform of 
government offices and Souvenir objects[16]. Malik, dkkexplain that Malay clothing has a function, namely: a) clothing as a cover of shame, as a cover for genitalia; b) clothing as a foster, which means forming character, personality, forming character so that the user knows himself and has good character; c) traditional customary clothing, which reflects the noble values in the customs and traditions that live in the community; d) clothing as a disaster repellent, namely: avoid the wearer from getting dangerous or disastrous; e) clothing upholds the nation, in the form of symbols and values in clothing[14].

\section{The VTS Learning Approach (VCT and Scientific)}

The 2013 curriculum has its own characteristics, namely the application of a scientific approach in the learning process so that the history learning in schools is also applied in a scientific approach. Scientific learning emphasizes the importance of collaboration and cooperation among students. The Scientific learning is more prioritizing to student center or learning orientation must lie in students, where they must be more active, innovative, creative, and critical in carrying out the learning process in the class. The implementation of a scientific approach in the 2013 Curriculum, in addition to helping create learning that meets process standards so as to improve the quality of learning carried out by teachers, can also help achieve complex learning and educational goals, including attitudes (religious attitudes and social attitudes), knowledge and skills [17].

The learning with a scientific approach is learning that consists of observing activities (to identify problems to be known), formulating questions and formulating hypotheses, collecting data with various techniques, analyzing data and drawing conclusions and communicating the results consisting of conclusions and also other findings outside the problem formulation to obtain knowledge, skills, and attitudes [18]. The scientific approach provides the opportunity for students to be more active in learning activities, including the learning history [19]. The implementation of learning which is oriented towards student activities with a scientific approach can improve the learning activities and competencies of students so that it is relevant in the history learning process that is more fun and meaningful. Because, if students are active and feel happy in the learning, history learning will be more memorable and meaningful.

Meaningful history learning can be done by integrating values into the learning process. The integration of values into the learning process can be done through a value education approach, namely VCT (Value Clarification Technique). VCT is one of the learning techniques that can realize the goal of achieving value education [4]. The VCT approach places emphasis on helping students learn about their own feelings and actions, to increase their awareness of their own values [20]. The VCT learning approach can make learning more meaningful and students can feel the benefits when the values that have been found are analyzed by students must be aligned with the values that are inherent in the students [2]. Furthermore, Sutarjo in Sadono\&Masruriexplain VCT is a teaching technique to assist students in finding and determining valuesthat are considered good in dealing with a problem through the process of analyzing existing and embedded values in themselves[21]. Hall and Simon in Adisusilo saidthe process of determining values and attitudes includes seven sub-processes or aspects which are usually classified into three categories, as follows:

1. Choosing

a. Choose freely.

b. Choose from various alternative.

c. Choose fromvarious alternatives after hold consideration of the various consequences.

2. Appreciate/ uphold

a. Appreciate and feel happy with the choice.

b. Willing to acknowledge/confirm his choice in public.

3. Action

a. Do/actualization according to their choice.

b. Repeatedly acting according to their choices until finally becoming a pattern of life[20]. 
The VCT approach emphasizes the free selection and determination of values by students and attitudes towards them. The selection and determination of values is done independently with a variety of value considerations made by students. Furthermore, students live and express values to act according to the value of their choice. One of the characteristics of VCT is the process of cultivating values carried out through the process of analyzing the values that already exist in students and then aligning them with the new values that will be invested [22].

\section{Integration of SiakSongket Weaving Values through Value Clarification Technique}

In the learning, students are expected to be able to understand and live the values they get, so that values can be internalized well to students [8]. The meaningful history learning process (The 2013 curriculum) can be implemented through a scientific learning model with the Value Clarification Technique approach. The values that are integrated into learning are values derived from local wisdom. The role of local wisdom in learning history is very important in order to be able to teach students to always be close to the real situations they face in everyday life and to help students to better understand each historical event in a better and more enjoyable way [8].
The history learning that has taken place so far has not yet integrated the values of local wisdom, so the integration of local valuesstill needs to be done. Because, one way to get students closer to historical material is to use local sources where the student lives [23]. Efforts to integrate local values can be done through history learning in schools, because in the 2013 curriculum with a scientific approach it can be implemented. This research produced a model of the development of the history learning that integrates the values of the SiakSongket Weaving through a scientific approach and the VCT value approach which can be called the VTS Learning Models (VCTScientific). The VTS model seeks to enhance the history learning that is more meaningful, as a solution to overcome the problems of the history learning which are monotonous, passive, and only memorizes historical facts. This model also not only requires students to follow positive values understood and instilled by the teacher, but also able to choose and consider values so that they can be used as a reference in selfactualization in daily life. The following is explained the syntax of history learning with the Value Clarification Technique approach in a scientific learning framework in accordance with the 2013 Curriculum, namely:

Table 2. The VTS Learning Models (VCT-Scientific)

\begin{tabular}{|c|c|c|}
\hline \multicolumn{2}{|c|}{ Learning Stage } & \multirow{2}{*}{$\begin{array}{l}\text { Learning Activities } \\
\text { The students follow the preliminary } \\
\text { directions, observe, look, and listen to the } \\
\text { teacher's initial explanation and record the } \\
\text { assignments given by the teacher. }\end{array}$} \\
\hline Observing & & \\
\hline Questioning & Choosing Values & $\begin{array}{l}\text { Students ask questions about the information } \\
\text { that is not understood or requires additional } \\
\text { information from what is observed. Form a } \\
\text { study group and receive teaching materials } \\
\text { based on the SiakSongket woven values given } \\
\text { by the teacher and choose values that are } \\
\text { relevant to students' self-development }\end{array}$ \\
\hline $\begin{array}{l}\text { collecting } \\
\text { information }\end{array}$ & $\begin{array}{l}\text { Expressing } \\
\text { Values }\end{array}$ & $\begin{array}{l}\text { The students collect information from various } \\
\text { sources to complete the materials needed to } \\
\text { do the task. Live and internalize the values }\end{array}$ \\
\hline
\end{tabular}




\begin{tabular}{|c|c|c|}
\hline Associating & & $\begin{array}{l}\text { that have been chosen into them. } \\
\text { The students process and write reports on the } \\
\text { results of the discussion. Discuss each other in } \\
\text { groups by expressing the values chosen. }\end{array}$ \\
\hline Communicating & $\begin{array}{l}\text { Values } \\
\text { Actualization }\end{array}$ & $\begin{array}{l}\text { The students present the results of discussions } \\
\text { and questions and answers between groups } \\
\text { and actualize themselves on the choice of } \\
\text { values through argumentation and good } \\
\text { attitude. The students also listen to } \\
\text { reinforcement from the teacher and reflect on } \\
\text { learning, do the test, and close the learning } \\
\text { with prayer together. }\end{array}$ \\
\hline
\end{tabular}

Based on the results of this research and development, it is suggested that the VTS model is expected to be an effective model in integrating values derived from local wisdom into the learning process of history at school. The combination of scientific approaches and VCT is a major point in the development of this model, which seeks to realize value-based history learning. In addition, the VTS model can also effectively enhance the learning process of history to be more meaningful and reflective learning. So that the students can learn the values contained in the SiakSongket weaving which is local wisdom of Malay Riau, hopefully also can take the wisdom and values that

\section{CONCLUSIONS}

The innovation of learning continues to be made to achieve the ideal learning that is relevant to the needs and challenges of the 21st century. The 21st-century learning is expected to be able to train and instill a democratic attitude for learners and create a fun learning atmosphere so that students are able to learn by developing their potential. Fun learning is a learning that is scarred and meaningful for students.

Meaningful history learning can be done by interpreting the values in the learning process of history. The integration of values into the learning process can be done with a value education approach namely VCT (Value Clarification Technique) in Scientific Learning Framework (The Curriculum 2013). The combination of scientific approaches and the VCT is a major point in the development of this VTS models, striving to realize local values- correspond to him. The history learning will be much more meaningful because it does not merely memorize historical facts.

In addition to theoretical reasons as described previously, that many of previous research has made the development of the model by integrating local wisdom values into learning through VCT approach. The development of models with the VCT approach is very effective in integrating values derived from local wisdom, fulfilling the need for innovative learning models, and also impacting to improve the quality of learning and the ability students in school [2];[4]; [21]; [24].

based history learning. So that the students can take the wisdom and learn the values contained in the SiakSongket weaving which is the local wisdom Malay Riau. The history learning will be much more meaningful because it does not merely memorize historical facts.

The VTS Model provides an emphasis on the process of integrating values through the VCT approach, namely: (1) Choosing values, this stage is made for the selection and determination of the free by the students and attitudes towards it. The selected values derived from the local wisdom of SiakSongket weaving. The selection and determination of the value are done independently with various value considerations that the learners have. (2) Expressing values, the students internalize the values of SiakSongket weaving that has been selected into him. (3) Values actualization, the students actualize themselves over their chosen values through arguments and good manners. 
Hopefully, the history learning model innovations impact more to improve of reflective learning and meaningful learning.

\section{REFERENCES}

[1] Tandirerung, N., Hasan, \& Nuraedah. (2017). Meningkatkan Hasil Belajar Sejarah Melalui PendekatanPembelajaran Konstruktivistik Pada Siswa Kelas XI IPS SMA Muhammadiyah 1 Palu. e Jurnal Katalogis, 5(7), pp. 158-168.

[2] Ekasari, P. N. (2017). Pembelajaran Berbasis Nilai Pada Mata Pelajaran Sejarah Melalui Model VCT(Value Clarification Technique). Sejarah dan BudayA, 11(2), pp. 192-198.

[3] Sayono, J. (2013). Pembelajaran Sejarah di Sekolah: Dari Pragmatis ke Idealis. Sejarah danBudaya, 7(1), pp. 9-17.

[4] Suryani, N. (2013). Pengembangan Model Internalisasi Nilai Karakter Dalam Pembelajaran Sejarah Melalui Model Value Clarification Technique. Paramita, 23(2), pp. 208-219.

[5] Trianto. (2010). Mendesain Model Pembelajaran Inovatif - Progresif. Jakarta: Kencana Prenada MediaGroup.

[6] Umasih. (2016). Peran Strategis Pendidikan Sejarah Dalam Pembentukan Karakter Bangsa. SeminarNasional "Pendidikan Ilmu-Ilmu Sosial Membentuk Karakter Bangsa Dalam Rangka Daya Saing Global" (pp. 475-484). Makassar: Himpunan Sarjana Ilmu-ilmu Sosial.

[7] Amiruddin. (2016). Peran Pendidikan Sejarah Dalam Membangun Karakter Bangsa. SeminarNasional "Pendidikan IlmuIlmu Sosial Membentuk Karakter Bangsa dalam Rangka Daya Saing Global" (pp. 193202). Makassar: Himpunan Sarjana Ilmuilmu Sosial.

[8] Pernantah, P. S. (2018). Pembelajaran Sejarah Terintegrasi Nilai Local Wisdom. Yogyakarta: PhoenixPublisher.

[9] Garvey, B., \& Krug, M. (2015). ModelModel Pembelajaran Sejarah di Sekolah Menengah (Diterjemahkan oleh Dian Faradilla dari Buku Models of History Teaching). Yogyakarta: Penerbit Ombak.

[10] Susanto, H. (2014). Seputar Pembelajaran Sejarah: Isu, Gagasan, dan Strategi
Pembelajaran. Banjarmasin: Aswaja Pressindo.

[11] Hasan, S. H. (2012). Pendidikan Sejarah Untuk Memperkuat Pendidikan Karakter. Paramita, 22(1), pp. 81-95.

[12] Lestari, S., \& Riyanti, M. T. (2017). Kajian Motif Tenun Songket Melayu Siak Tradisional Khas Riau.Dimensi DKV, 2(1), pp. 33-48.

[13] Guslinda. (2017). Kerajinan Tenun Songket Melayu Riau Untuk Pelestarian Kearifan Lokal. JurnalPigur, 2(1), pp. 124130.

[14] Malik, d. (2015). Corak dan Ragi Tenun Melayu Riau. Yogyakarta: Adicita Karya Nusa.

[15] Dasrol. (2013). Analisis Terhadap Hambatan Pelaksanaan Perlindungan Hukum Tenun Siak diKabupaten Siak Berdasarkan Undang-Undang Nomor 19 Tahun 2002 Tentang Hak Cipta. Jurnal Hukum dan Pembangunan, 43(1), pp. 1-26.

[16] Guslinda, \& Kurniaman, O. (2016). Perubahan Bentuk, Fungsi, dan Makna Tenun Songket Siak PadaMasyarakat Melayu Riau. Jurnal Primary, 5(1), pp. 2942.

[17] Susilana, R., \& Ihsan, H. (2014). Pendekatan Saintifik dalam Implementasi Kurikulum 2013Berdasarkan Kajian Teori Psikologi Belajar. Edutech, 13(2), pp. 183195.

[18] Permata, E. A. (2014). Implementasi Pendekatan Saintifik Dalam Kurikulum 2013 Pada PembelajaranSejarah. Indonesian Journal of History Education, 3(1), pp. 11-16.

[19] Ratnasari, E. (2017). Pengaruh Pendekatan Saintifik Terhadap Sikap Ilmiah Dalam Pembelajaran Sejarah Kelas XI IPS 1 di SMA Ma'arif Sukorejo. Avatara, e-Journal Pendidikan Sejarah, 5(1), pp. 1-14.

[20] Adisusilo, S. (2014). Pembelajaran NilaiKharakter: Kontruktivisme dan VCT sebagai Inovasi Pendekatan Pembelajaran Efektif. Jakarta: PT RajaGrafindo Persada.

[21] Sadono, M. Y., \& Masruri, M. S. (2014). Keefektifan VCT Dalam Pembelajaran Sejarah untuk Meningkatkan Nilai Nasionalisme, Demokrasi, dan Multikultural. Harmoni Sosial, 1(1), pp. 7182. 
[22] Sari, I. P., \& Suwandi, I. K. (2018). Nationalism Character Building by Value Clarification Technique (VCT). The $1^{\text {st }}$ PGSD UST International Conference on Education (pp. 73-80). Yogyakarta: PGSD Universitas Sarjanawiyata Tamansiswa. Clarification Technique Integration Model to explore the local Wisdom in Historical Learning.

[23] Romadi, \& Kurniawan, G. F. (2017). Pembelajaran Sejarah Lokal Berbasis Foklore untuk MenanamkanNilai Kearifan Lokal Kepada Siswa. Sejarah dan Budaya, 11(1), pp. 79-94.

[24] Pratama, Y., Joebagio, H., \& Sariyatun. (2017). The development of Means-Ends Analysis and ValueClarification Technique Integration Model to explore the local Wisdom in Historical Learning. Journal of Education and Learning, 11(2), pp. 179-187. 